\title{
Talent Acquisition Under Human Resource, In Satlink Consultancy Services, Chennai
}

\author{
Ravimohan, S .Praveen Kumar, Nivetha
}

\begin{abstract}
Analysis of requirements given by clients \& acquire talent. Effective initial screening for the tenured to check the stability.Responsible for the back end work of screening applicants, mapping the resumes with the requirements and maintaining database for future references.Involved in Sourcing of Profiles via various mediums to match the requirements in terms of suitability, lead time and salary guidelines.Coordinating for documentation work. Maintained and corrected the database of the joiners in the company on a regular basis, Coordinating for the Background Checks.

Maintained and updated files and retrieve relevant information as and when required. Follow up with offered Candidate till joining. Taking care of Joining of New Hires. To prepare and complete his/her Personal File. Issuing Offer Letters / Appointment Letters.
\end{abstract}

Keywords :Clients,Screening,Short listing..

\section{INTRODUCTION}

The recognizable proof, relationship building and choice of individuals who have unique, inventive, creative or potentially mental blessings who can impact, add to and additionally drive income to our business by applying phenomenal exertion, practicing solid relationship the board and giving competitors and enlisting pioneers a definitive encounter. [1]

All things considered, similarly as Customer Acquisition depicts the general vital procedure around recognizing market divisions, focusing on customer prospects, running direct showcasing efforts, selling and accepting the request (for example securing another client), so Talent Acquisition includes all the sub-forms around finding, pulling in and connecting exceptionally capable people into your association. [2-4]

As a matter of first importance, 'ability obtaining' structures a piece of an a lot more extensive vital methodology in the corporate mission to pick up and continue an upper hand in the present commercial center. Different angles incorporate ability advancement, maintenance and change, these are essentially internal confronting, while the previous is outward looking.[3-4]

The talent acquisition in Human recourse is very much essential and is initiated with interviews and that to if the

Revised Manuscript Received on July 22, 2019

Ravimohan, Department of Management studies,Bharath Institute of Higher Education and Research,Chennai,India

S..Praveen Kumar Department of Management studies,Bharath Institute of Higher Education and Research,Chennai,India

Nivetha, Department of Management studies,Bharath Institute of Higher Education and Research,Chennai,India. requirement / Hiring is for international Bpo's, Quality is considered to be the most crucial Factor, Because the Concern is for the international customer's that seek assistance over the phone, the issue may be of Technical or a silly question, but the solution has to be prompt \& quick followed by the quality, because each \& every call is monitored for the quality purpose followed by the AHT (Average Handling Time) \& C.SAT (Customer Satisfaction).[6]

Talent acquisition in an international Bpo's synchronizes the effectiveness of a particular concerned process.

Human asset the executives (HRM) is a way to deal with the administration of individuals, in light of four major standards. In the first place, HR are the most significant resources of an association have and their compelling administration is the way to progress. Second this achievement is destined to be accomplished if the individual arrangements and strategies of the venture are firmly connected with, and make a noteworthy commitment to, the accomplishment of corporate targets and key plans. Third the corporate culture and qualities, hierarchical atmosphere and administrative conduct that exude from that radiate from that culture and qualities, authoritative atmosphere and administrative conduct that exude structure that culture and the qualities may should be changed or strengthened, and that constant exertion beginning structure the top, will be required to get at that point and followed up on. At last, HRM is worried about coordination getting every one of the individuals from the association included and cooperating with a feeling of basic reason [7]

HRM is a key way to deal with the obtaining, inspiration and advancement and the executives of the association's HR. It is a specific field that endeavors to create projects, approaches and exercises to advance the fulfillment of both individual and authoritative needs, objectives and goals. It is dedicated to forming a corporate culture, and presenting projects witch reflect and bolster the guiding principle of an endeavor and guarantee its prosperity. HRM is proactive as opposed to responsive, for example continually anticipating what should be done and afterward doing it, rather instructed holding on to be told about enlisting, paying or preparing individuals, or managing worker relations issues as they emerge. The procedures for the utilization of HRM will incorporate numerous well-known elements of staff troughs, for example, labor arranging, choice, execution evaluation, compensation organization, preparing and the board advancement. Uncommon projects intended to improve correspondence frameworks: association, responsibility and efficiency will overlay these.[8] 


\section{II.NEED FOR CHOOSING TOPIC:}

There are many significant reasons that made me inquisitive \& curious to choose this topic is because it is helpful to analyze the Human recourse policies, that is very much essential in extracting the knowledge of what is happening across, the Human recourse desk and that may lead in acquiring the best talent $\&$ to deliver the quality to make the things happen as per the compatibility of the management. 1.Understanding workforce socioeconomics (current and future) [9]

2 Identifying monetary issues affecting authoritative supportability

3 Identifying hierarchical and social issues affecting ability procurement

4 Knowledge of industry patterns and developing issues

\section{Linking Organizational Strategy to HR Strategy}

6 Understanding the authoritative methodology

7 Translating the authoritative methodology into a HR system

8 Reviewing key parts of the HR methodology

9 Identifying ability procurement and maintenance issues

10 Designing and Implementing a Talent Acquisition Strategy

11 What is an Employer of Choice? [10]

12 Demystifying the generational ramifications on enrollment

13 Reviewing the base components of an ability procurement methodology

14 Utilizing ability procurement devices and formats

15 Identifying contemplations when actualizing an ability securing strategyIII . Explanation OF PROBLEMS:

1. No weighting of inquiries questions

2. Poor setting for the meeting

3. Lacking follow-up inquiries

4. Inability to check with previous businesses

5. Utilization of employing quantities

6. Inability to post openings

7. Tapping successors

8. Steady loss rate.

\section{Untrained questioners}

10. Improper inquiries

11. Inability to give sensible convenience of debilitated candidates

12. Inability to advise ineffective contenders of the choice

13. Inability to give the new representative a substantive direction of the activity.

\section{Surged choice procedure[11]}

\section{III.TALENT ACQUISITION: SOURCING FROM JOB PORTALS}

- Analysis of requirements given by Clients.

- $\quad$ Search for prospective candidates using the Portals, Job Posting, Mass Mailing and consultants.

- Screening and Short listing of the candidates as per the requirement at initial level.

- Maintaining database of the resume for all platforms and skill sets.

- Short listing resumes by evaluating the candidates on technical \& communication skill

- Coordinating the Walk-in interviews.['12]

\section{PRE - RECRUITMENT FUNCTIONS:}

- Sourcing Profiles for various Job portals, Vendors, referrals \& Head Hunting.

- $\quad$ Scheduling \& Coordinating Interview schedules after short listing the profiles from all sources.

- Coordination \& collection of job description from various teams.

- Collection of required documents from the candidates and verifying the details.

- Calculation of salary \& their respective levels to be determined based on the company policy.

- Negotiation of salary details with the candidates \& preparing offer letters.

- Proper coordination until the candidates joins on-board.

- $\quad$ Preparing Recruitment tracker \& reports.[13]

- SECONDARY OBJECTIVE' $\mathrm{S}$

\section{V..POST RECRUITMENT FUNCTIONS:}

- Payroll Preparation.

- $\quad$ Preparing Statutory reports (PF, ESI etc).

- Coordination \& consolidation of Payroll inputs from different departments.

- Monitoring \& Generation reports on Leave, Attendance $\&$ other payroll related reports.

- Coordinate on the Employee transfer \& issuing transfer letters.

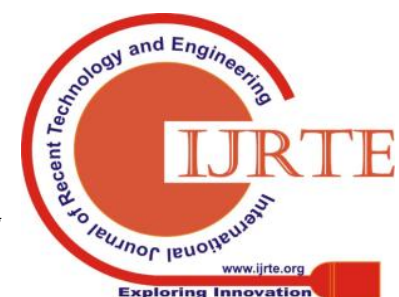


- Coordination on Performance Management activities.

\section{CLIENT INTERACTION:}

- Regular interaction with clients.

- $\quad$ Requirements from clients[14]

\section{VII. .PACKAGE NEGOTIATION}

- Handled grievances related to salary issues, location issues.

- Issues related to enhance the package $\&$ incentives slabs

\section{A. Exit Formalities:}

- Taking exit interview of whoever is leaving and maintaining the feedbacks received at the time of exit interview.

- Involved in full and final settlements for the resigned associates[15]

CLIENTS HANDLED IN SATLINK CONSULTANCY SERVICES:

INTERNATIONAL:

SUTHERLAND GLOBAL SERVICES, CYBERNET SLASH SUPPORT ,ALLSEC TECHNOLOGIES , E4E TECHNOLOGIES , INTELENET , HCL BPO , SITEL ,

DELL ,WIPRO.

DOMESTIC:

EUREKA OUTSOURCING \& NET AMBIT

"THERE ARE VARIETIES OF CLIENTS IN TERMS OF SATISFYING THE NEEDS OF THEIR REQUIREMENTS."

\section{VIII.RESEARCH METHODOLOGY}

It's the arrangement of conditions for collection and analysis of data in a manner that aim to combine relevance to the research purpose. There are two primary methodologies for conducting any research; it's through primary data and secondary data. Choice between the two is made whichever appears to be best in terms of convenience, ease of use, and trust in the method.[16]

- PRIMARY DATA -

- QUESTIONNAIRE METHOD

- TELEPHONIC INTERVIEW

- OBSERVATION METHOD

- PERSONAL INTERVIEW

\section{JUSTIFICATION}

The topic chosen for the thesis has a wide scope in the present as well as for forth coming year. It will help in understanding the effectiveness of the recruitment \& selection of human work force system and drawback of it's as well. It will help to fulfill the gap between the management and employees.[17]

Personally, for me it's a learning experience. A Practical application of all what $i$ have learnt during my MBA and moreover i see my future in hr so it's bound to help me as well. As a future hr manager I am learning the most important part of management i.e. on how to make your employee work for the organization while taking care of there career and needs \& what are the preferences of employees towards ITES \& BPO.

\section{X.SAMPLING}

The total sample size for this project will be 100 employees which includes fresher's as well as tenured from various corporate, This helped me to analyze to actual reason of change from the employees.[18]

\section{- SECONDARY SOURCES- \\ - INTERNET (WEBSITES),JOBS PORTALS.(NAUKARI, MONSTERS , TIMES )}

- NEWSPAPERS

- MAGAZINES, INTERNET AND WEBSITES:

Such sites have two main features: Job boards and resume curriculum vitae (CV) database. Job boards allow member companies to post job vacancies. Alternatively, candidates can upload a resume to be included in searches by member companies. Fees are charged for job postings and access to search resumes. Since the late 1990s, the recruitment website has evolved to encompass end-to-end recruitment. Websites capture candidate details and then pool them in client accessed candidate management interfaces (also online). Key players in this sector provide e-recruitment software and services to organizations of all sizes and within numerous industry sectors, who want to e-enable entirely or partly their recruitment process in order to improve business performance.

The online software provided by those who specialize in online recruitment helps organizations attract, test, recruit, employ and retain quality staff with a minimal amount of administration. Online recruitment websites can be very helpful to find candidates that are very actively looking for work and post their resumes online, but they will not attract the "passive" candidates who might respond favorably to an opportunity that is presented to them through other means. Also, some candidates who are actively looking to change jobs are hesitant to put their resumes on the job boards, for fear that their current companies, co-workers, customers or others might see their resumes.

\section{JOB SEARCH ENGINES}

The emergence of meta-search engines, allow job-seekers to search across multiple websites. Some of these new search engines index and list the advertisements of traditional job boards. These sites tend to aim for providing a "one-stop shop" for jobseekers. However, there are many other job search engines which index pages solely from employers' websites, choosing to bypass traditional job boards entirely. These vertical search engines allow job-seekers to find new positions that may not be advertised on traditional job boards, and online recruitment websites. There are certain job portals that are used to browse suitable profiles from the internet, as per the requirements of clients, it play a very crucial role in fulfilling the targets for the clients, The different job portals used for the sourcing of profiles make a huge difference in terms of, targeting the employees.[19] 
The different job portals that are used to source the profile are,

\section{- $\quad$ MONSTER INDI}

- TIMES JOB

\section{- NAUKARI}

These job portals are very crucial in terms of achieving the needs of the clients, job portals are termed as the key in "human

1. Which method is the most preferred for recruitment?

TABLE 1

\begin{tabular}{|l|l|l|}
\hline $\begin{array}{l}\text { MOST PREFERRED } \\
\text { FORMOF RECRUITMENT }\end{array}$ & NO OF RESPONDENT & PERCENTAGE \\
\hline ADVERTISEMENT & 22 & $22 \%$ \\
\hline REFERRALS & 36 & $36 \%$ \\
\hline CAMPUS RECRUITMENT. & 16 & $16 \%$ \\
\hline $\begin{array}{l}\text { JOB POSTINGS/BULK } \\
\text { MAILING. }\end{array}$ & 26 & $26 \%$ \\
\hline TOTAL & 100 & $100 \%$ \\
\hline
\end{tabular}

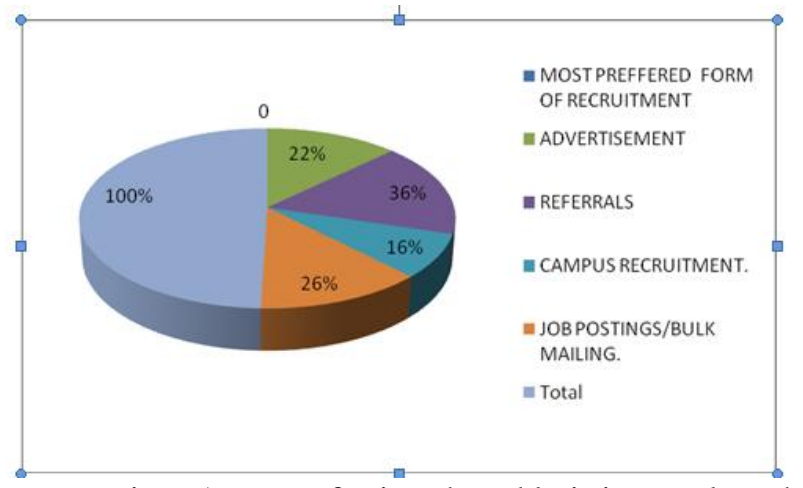

Interpretation: As per referring the table it is not clear that which is the most preferred form of recruitment, but still REFFERAL Dominates the list with $34 \%$ from the respondent.

2. Does working in a pure night shift give any is stressful \& disease friendly?

\section{TABLE 2}

\begin{tabular}{|l|l|l|}
\hline $\begin{array}{l}\text { MENTAL ISSUES } \\
\text { WORKING IN A NIGHT } \\
\text { SHIFT }\end{array}$ & RESPONCES & PERCENTAGE \\
\hline \multicolumn{1}{|c|}{ HEADACHE } & 22 & $22 \%$ \\
\hline DULL ACHES \& PAINS & 18 & $18 \%$ \\
\hline HIGH BLOOD PRESSURE & 22 & $22 \%$ \\
\hline INSUFFICIENT SLEEP & 38 & $38 \%$ \\
\hline TOTAL & 100 & $100 \%$ \\
\hline
\end{tabular}

\section{GRAPH 2}

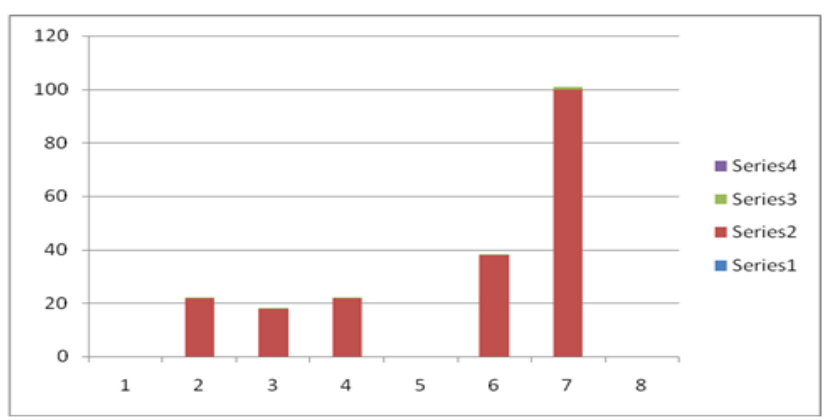

Interpretation: The responses that are drawn from the employees who work in a night shift, believes that, graveyard shift may prove harsh and hazardous \& may pose treat to health.

Favorable selection steps:

TABLE 3

\begin{tabular}{|l|l|l|}
\hline $\begin{array}{l}\text { FAVOURABLE } \\
\text { SELECTION } \\
\text { PROCEDURE }\end{array}$ & RESPONCES & PERCENTAGE \\
\hline WRITTEN TEST & 15 & $15 \%$ \\
\hline $\begin{array}{l}\text { PREMINILARY } \\
\text { SCREENING + GD }\end{array}$ & 25 & $25 \%$ \\
\hline HR ROUND & 40 & $40 \%$ \\
\hline ALL OF THESE & 20 & $20 \%$ \\
\hline TOTAL & 100 & $100 \%$ \\
\hline
\end{tabular}

\section{GRAPH 3}

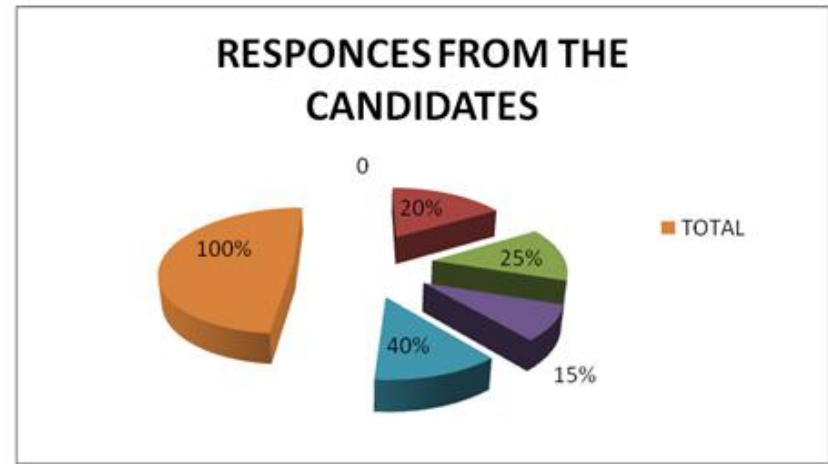

Interpretation: As per referring the table it is clear that only HR round is referred from the candidates that is $40 \%$. 4.Age group Comfortable working in Graveyard-shift?

\section{TABLE 4}

\begin{tabular}{|l|l|l|}
\hline $\begin{array}{l}\text { AGE } \\
\text { GROUPCOMFORTABLE } \\
\text { IN NIGHT SHIFT }\end{array}$ & RESPONCES & PERCENTAGE \\
\hline $18-30$ & 65 & $65 \%$ \\
\hline $31-45$ & 25 & $25 \%$ \\
\hline $45 \&$ ABOVE & 10 & $10 \%$ \\
\hline TOTAL & 100 & $100 \%$ \\
\hline
\end{tabular}

\section{GRAPH 4}

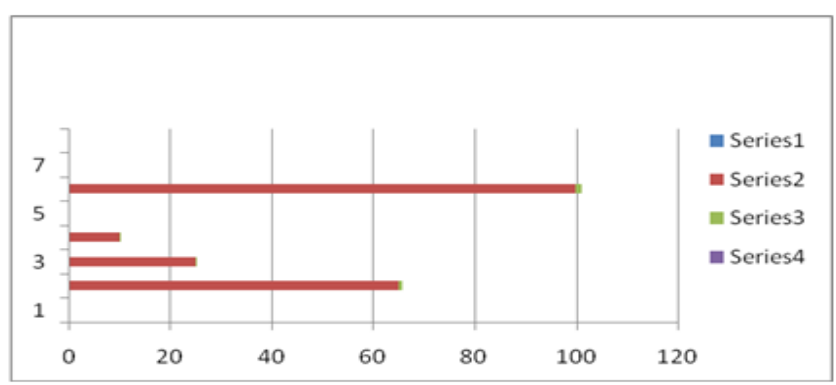

Interpretation: As per responces for grave yard shift is that most of the male only prefer to work in night shift i,e;40 \% \& only $25 \%$ of the women are comfortable with night shift. 5 .Will you be comfortable to sign a bond of 1 year ( to check the stability)

TABLE 5 


\begin{tabular}{|l|l|l|}
\hline $\begin{array}{l}\text { COMFORTABLE IN } \\
\text { SIGHINING A BOND }\end{array}$ & RESPONCES & PERCENTAGE \\
\hline YES & 82 & $82 \%$ \\
\hline NO & 18 & $18 \%$ \\
\hline TOTAL & 100 & $100 \%$ \\
& & \\
\hline
\end{tabular}

\section{GRAPH 5}

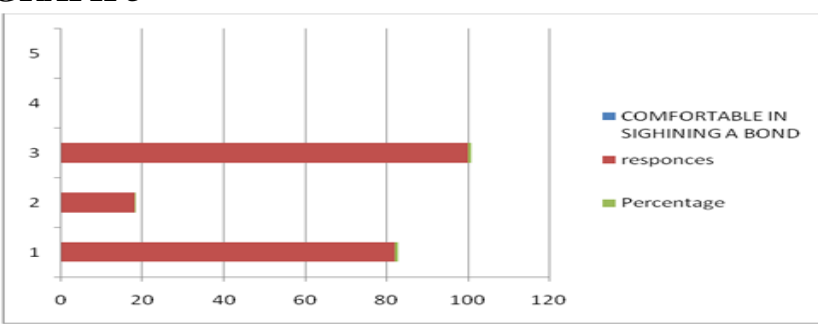

Interpretation: As per responces which I got is clear that siging a bond is an issue for bpo employees, with the most $82 \%$ are not comfortable

6 What motivates / inspires you to work for ITES/BPO?

TABLE 6

\begin{tabular}{|l|l|l|}
\hline MOTIVATING FACTOR & RESPONCES & PERCENTAGE \\
\hline PACKAGE & 42 & $42 \%$ \\
\hline FACILITIES & 34 & $34 \%$ \\
\hline CAREER & 24 & $24 \%$ \\
& & \\
\hline TOTAL & 100 & $100 \%$ \\
\hline
\end{tabular}

$\begin{aligned} & =1 \\ & =2 \\ & =3 \\ & \end{aligned}$

Interpretation: As per responses that I received from the candidates it is clear that the motivating factor remains the package in Bpo's to have a start.

7. What attracts you the most in terms of job profile?

\section{TABLE 7}

\begin{tabular}{|l|l|l|}
\hline $\begin{array}{l}\text { FACTOR THAT } \\
\text { ATTRACTS }\end{array}$ & RESPONCES & PERCENTAGE \\
\hline RESPONSIBILITIES & 45 & $45 \%$ \\
\hline CAREER & 55 & $55 \%$ \\
\hline TOTAL & 100 & $100 \%$ \\
\hline
\end{tabular}

\section{GRAPH 7}

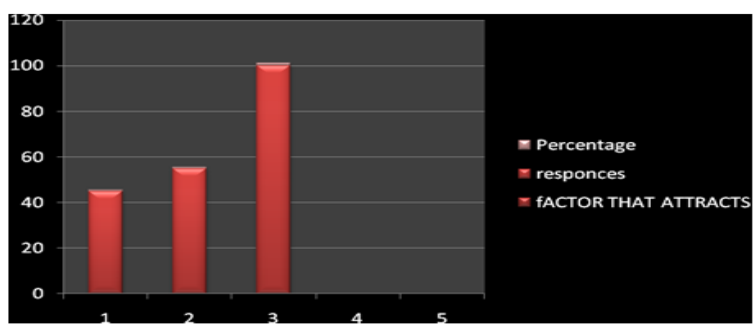

Interpretation: As per responses that were gathered in terms of the clause that attracts towards the job, is career than brand.

$-46-$

8. The reason for a change?

\section{TABLE 8}

\begin{tabular}{|c|c|c|}
\hline $\begin{array}{llr}\text { MOTIVATING } & \text { FACTOR } \\
\text { TO LOOK } & \text { FOR } \\
\text { CHANGE } & & \\
\text { HA }\end{array}$ & RESPONCES & PERCENTAGE \\
\hline PAY HIKE & 36 & $36 \%$ \\
\hline SUITABLE PROFILE & 34 & $34 \%$ \\
\hline CONTRACT EXPIRED & 22 & $22 \%$ \\
\hline $\begin{array}{l}\text { CONFLICT } \\
\text { SUPERIOR }\end{array}$ & 08 & $08 \%$ \\
\hline TOTAL & 100 & $100 \%$ \\
\hline
\end{tabular}

\section{GRAPH8}

\section{FACTOR FOR A JOB CHANGE}

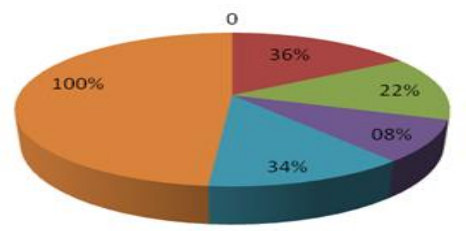

Interpretation: As per the responses that were gathered from the employees, it is clear that a reasonable hike in pay may be a reason to look for a job.

9. Reasons for attrition in BPO:

\section{TABLE 9}

\begin{tabular}{|l|l|l|}
\hline $\begin{array}{l}\text { REASONS FOR } \\
\text { ATTRITION }\end{array}$ & RESPONCES & PERCENTAGE \\
\hline GRAVEYARD SHIFT & 30 & $30 \%$ \\
\hline $\begin{array}{l}\text { INAPPROPRIATE CARRER } \\
\text { GROWTH }\end{array}$ & 25 & $25 \%$ \\
\hline PRESSURE & 15 & $15 \%$ \\
\hline HEALTH ISSUES & 30 & $30 \%$ \\
\hline TOTAL & 100 & $100 \%$ \\
\hline
\end{tabular}

\section{GRAPH 9}

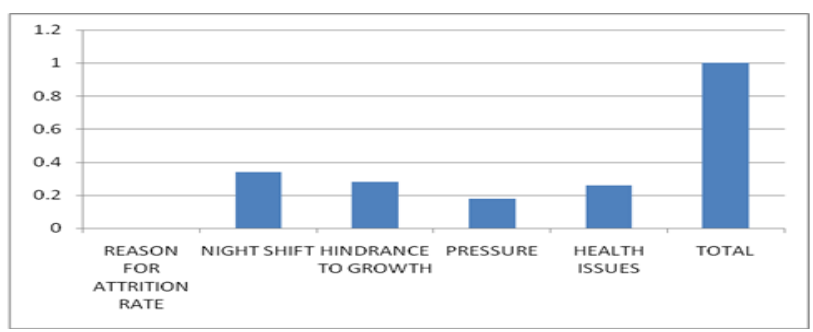

Interpretation: As per the statistics collected from the employees and inference from the graph, clearly indicates that night shift is the main reason for health issues that are increasing affecting the employees, to stay fit $\&$ breath free $\&$ mental stability is the key concern for the tenured/experienced employees.

10. Do you ever have to work on weekends and holidays?

TABLE 10

\begin{tabular}{|l|l|l|}
\hline $\begin{array}{l}\text { EVER YOUHAVE TO } \\
\text { WORK IN WEEKOFF'S }\end{array}$ & RESPONCES & PERCENTAGE \\
\hline ALWAYS & 78 & $78 \%$ \\
\hline SOMETIMES & 16 & $16 \%$ \\
\hline NEVER & 06 & $06 \%$ \\
\hline TOTAL & 100 & $100 \%$ \\
\hline
\end{tabular}

\section{GRAPH 10}

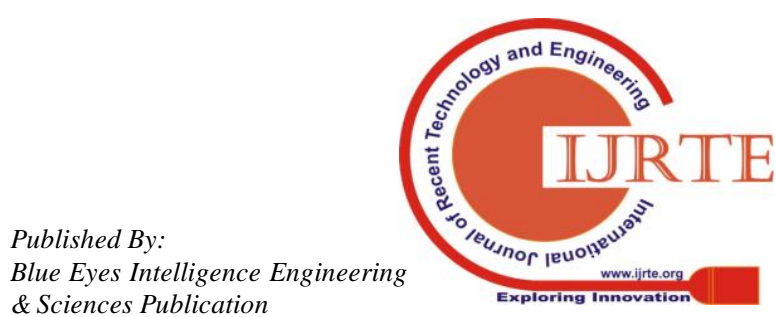




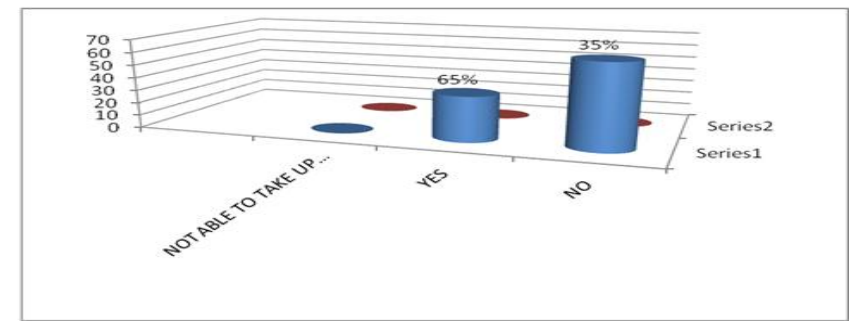

Interpretation: The graph clearly draws a conclusion that, most of the employees have to work in week offs and the week-end,I,e ; Saturdays \& Sundays.[21-25]

\section{XII.FINDINGS}

The word HRM has been used as a description of employee leadership with increased regulatory requirements.. Specially when it deals with talent acquisition in the multinational firms Human recourse has to be effective \& analytical in order to judge the candidates, more-over the stability, because it may be an issue after 3 or 4 months, then it can reduce the effectiveness of an organization at the same time it can hamper the attrition rate, that can question human resource desk later.

In term of the practical exposure, I was thrown into the ocean of challenges, with regards to my role as an HR trainee I traced many points \& findings like;

\section{B. Offer-rejects from the candidates.}

The study of offer rejects made some time's the situation as more worst as it,has to prompt before interviewing

\section{Night shift issues mostly with women}

THE most of the prominent findings of the study was, the issues of rotational shifts, that are more in to graveyard, with the women \& married employees.

\section{Package issues.}

The main issue that is bothering the employees, is the better package, but the maximum package offered to an employee in bpo would be 3.8, that to with an most experienced

- $\quad$ Profile management issues.

- Insufficient knowledge of job portals.

- Stability is the most concerned issue for the companies.I

- Talent acquisition

- Knowledge how the job portals works.

- Relocation issues.

This issue is the concern for most out-station employees who are ready for relocation.

\section{XII.RESULTS:}

Suggestions for the improvement in terms of HR-Department to make selection $\&$ recruitment to be more effective are mentioned below:

Immediate Follow-up at the required time for the candidates to offer them a job, for which they are desperate, because no one waits until the best offer is conveyed to him,an ignorance towards follow-up may lead to rejection.[20]

- To work on attrition rate.

- Proper follow-up for the potential candidates.

- To have a track record of each \& every candidate.
- To boost up employees with a career orientation programme

- $\quad$ Follow up for grievance system.[25-29]

- To cut $\&$ reduce the interview time for experienced.

- $\quad$ Immediate feedback.

- Affirm client interaction.

- Sound management system to maintain a tune in work-force.

- $\quad$ Proper mail system for the immediate feedbacks.

- To delegate the power to the juniors to make them conscious of the problems experienced by the HR department.

- $\quad$ Multi-Tasking[30-33]

\section{XIII.DISCUSSION}

The scope for further studies is always dependent on the execution that is operated in the present scenario \& hence incorporates the future need \& scope in a long run, because human resource in the prime department of the organization that understands the needs of the organization and fetches the suitable profiles in time of dire-straits for the organization.

The scope for the future studies will always play a crucial part in human resource to attract the needs of the organization \& to run successfully with the potential candidates; however the scope related to human resource would be:

- Present Human resource culture.

- Client' s requirement.

- $\quad$ Need for manpower.

- Sectors needs to be targeted

- $\quad$ Reason for attrition rate \& ways to eradicate it.

- $\quad$ Employee friendly zone.

\section{XIV.CONCLUSION}

Having considered the adjustments in varying backgrounds the HR arrangement is a noteworthy device to mend the HR to rethink their probability. Because of scaling back the remaining burdens are powers on the couple of representatives. Accordingly it is significant for the association to keep every one of its workers in a total fulfillment level to improve their assurance which will bring about the high efficiency of the association. In light of this situation, the present examination features the requirement for preparing,

appropriate treatment of complaints arrangement of clean workplace and so on; the critical discoveries will add to detail and faultless system which will cross over any barrier between what they are and what they should be.

In Chennai the study was led to discover the fulfillment level of the fulfillment level of the representatives in the association and HR approaches contributing towards increment of fulfillment level of the workers 
and about its viability achievement esteem expansion changes brought sent and so forth; this criteria have been assessed basically to discover potential proposals so that in future fulfillment level program will be taken genuine by the association.To work in Satlink Consultancy services, with basics of human resource \& client interaction, gave the fullest $\&$ nurtured the talent in terms of being a successful human resource, with the in-depth knowledge of working on job-portals \& sourcing the suitable profile in terms of fulfilling clients requirement.

\section{REFERENCES}

1) BharthVajan R., Ramachandran S.,Psychographic dimensions of training,2016,International Journal of Pharmacy and Technology,V-8,I-4,P-23727-23729

2) Balakrishnan P., Bharthvajan R.,A study on human resource planning in hospitals in Chennai City,2014,International Journal of Applied Engineering Research,V-9,I-22,P-7503-7507

3) Priyadarsini P., Bharthvajan R.,Role of emotional intelligence training programme in reducing the stress of the nurses,2014,International Journal of Applied Engineering Research,V-9,I-22,P-7411-7421

4) Kerinab Beenu G., Bharthvajan R.,Empirical analysis on the cosmetic buying behavior of young women in South India,2014,International Journal of Applied Engineering Research,V-9,I-22,P-7361-7366

5) Balakrishnan P., Bharthvajan R.,Whistling in the wind,2014,International Journal of Applied Engineering Research,V-9,I-22,P-7586-7593

6) Krishnan B., Peter M.,Health hazards of Indian Bpo employee-an alarming issue, 2014,International Journal of Applied Engineering Research,V-9,I-22,P-7336-7341

7) Kerinab Beenu G.H., Peter M.,Role of insurance in economic development,2014,International Journal of Applied Engineering Research,V-9,I-22,P-7532-7539

8) Balakrishnan P., Peter M., Priyadarsini P.,Efficiency of safety measures for wellbeing of employees in manufacturing industry,2014,International Journal of Applied Engineering Research,V-9,I-22,P-7376-7382

9) Anbarasi M., Praveen Kumar S.,Online sales promotions of herbal products and its effectiveness towards tanisha.com,2019,Indian Journal of Public Health Research and Development,V-10,I-1,P-195-200

10) Anbarasi M., Praveen Kumar S.,Various online marketing and promotions strategies to improve the validation towards the organic products in the pharmaceutical sectors,2019,Indian Journal of Public Health Research and Development,V-10,I-1,P-263-269

11) Loganathan R., Praveen Kumar S.,Grievance handling a key factor for solving issues of employees in an organization,2014,International Journal of Applied Engineering Research,V-9,I-22,P-7483-7491

12) Loganathan R., Praveen Kumar S.,Study on preference of private labe brands in super and Hypermarkets,2014,International Journal of Applied Engineering Research,V-9,I-22,P-7327-7335

13) Smitha M., Praveen Kumar S.,Understanding stress and its managementamong the nurses in Chennai city,2014,International Journal of Applied Engineering Research,V-9,I-22,P-7560-7565

14) Kerinab Beenu G.H., Praveen Kumar S.,A study on the investment behavior of Chennai investors in mutual fund schemes,2014,International Journal of Applied Engineering Research,V-9,I-22,P-7520-7525

15) Loganathan R., Praveen Kumar S.,Retention strategies key for organizational productivity,2014,International Journal of Applied Engineering Research,V-9,I-22,P-7443-7447

16) Pavithra J., Ganesan M., Brindha G.,State wise analysis of microfinance sector in India,2016, International Journal of Pharmacy and Technology,V-8,I-4,P-23417-23432

17) Pavithra J., Ganesan M.,A comparative study on microfinance in India and abroad,2016,International Journal of Applied Business and Economic Research,V-14,I-8,P-5471-5476

18) Pavithra J., Ganesan M.,A study on awareness and impact of micro-financial schemes,2016,International Journal of Applied Business and Economic Research,V-14,I-8,P-5449-5460

19) Senthilmurugan P., Pavithra J.,Consumer preference towards organised retailing with reference to Big Bazaar,2014,International Journal of Applied Engineering Research,V-9,I-22,P-7469-7475

20) Senthilmurugan P., Pavithra J.,Implication of social media marketing in growing healthcare industry,2014,International Journal of Applied Engineering Research,V-9,I-22,P-7448-7456

21) Loganathan R., Pavithra J.,Consumer perception towards private label brand over other brands in super markets and hypermarkets,2014,International Journal of Applied Engineering Research,V-9,I-22,P-7355-7360
22) Kerinab Beenu G., Pavithra J.,Tradeâ€"off between liquidity and profitability in logistics industry,2014,International Journal of Applied Engineering Research,V-9,I-22,P-7398-7401

23) Kerinab Beenu G., Pavithra J.,A study on the prospective consumerâ€ TM $_{S}$ perception towards utility cars in Chennai city,2014,International Journal of Applied Engineering Research,V-9,I-22,P-7526-7531

24) Pavithra J., Dilli Babu P., Ambuli T.V.,A study on budgetary control at Maruti Service Masters, Chennai,2014,International Journal of Applied Business and Economic Research,V-12,I-2,P-151-161

25) Pavithra J., Dilli Babu P., Ambuli T.V.,A study on customer satisfaction of retro Garments Pvt Ltd, Chennai,2014,International Journal of Applied Business and Economic Research,V-12,I-2,P-381-391

26) Kerinab Beenu G.H., Pavithra J., Senthilmurugan P.,A study on the influence of promotional activities for TATA ARIA among consumers in Chennai,2014,International Journal of Applied Engineering Research,V-9,I-22,P-7572-7578

27) Vijayaragavan S.P.,An investigative expert that's general FBG sensors,International Journal of Mechanical Engineering and Technology,V-8,I-8,PP-1500-1505,Y-2017

28) Vijayaragavan S.P.,Equalization routing protocol for Wi-Fi sensor strategy,International Journal of Mechanical Engineering and Technology,V-8,I-8,PP-1662-1666,Y-2017

29) Karthik B., Kiran Kumar T.V.U., Vijayaragavan P., Bharath Kumaran

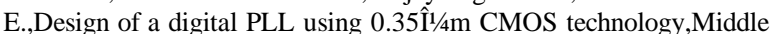
East Journal of Scientific Research,V-18,I-12,PP-1803-1806,Y-2013

30) Kanniga E., Selvaramarathnam K., Sundararajan M.,Kandigital bike operating system,Middle - East Journal of Scientific Research, V

31) Jasmin M., Vigneshwaran T., Beulah Hemalatha S.,Design of power aware on chip embedded memory based FSM encoding in FPGA,International Journal of Applied Engineering Research,V-10,I-2,PP-4487-4496,Y-2015

32) Jasmin M.,Optimization techniques for low power VLSI circuits,Middle East Journal of Scientific Research,V-20,I-9,PP-1082-1087,Y-2014

33) Jasmin M., Vigneswaran T.,Fuzzy controller for error control of on - Chip communication,2017 International Conference on Algorithms, Methodology, Models and Applications in Emerging Technologies, ICAMMAET 2017,V-2017-January,I-,PP-1-5,Y-2017

\section{AUTHORS PROFILE}

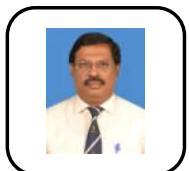

Ravimohan ,S Assistant Professor, Department of Management Studies,Bharath Institute of Higher Education and Research

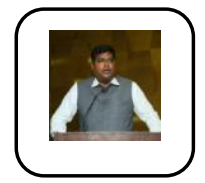

S .Praveen Kuma Professor, Department of Management Studies, Bharath Institute of Higher Education and Research.

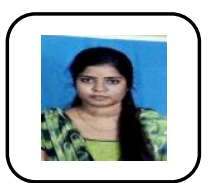

Nivetha Student Department of Management Studies, Bharath Institute of Higher Education and Research 